Tropical Journal of Pharmaceutical Research April 2021; 20 (4): 673-680

ISSN: $1596-5996$ (print); 1596-9827 (electronic)

(C) Pharmacotherapy Group, Faculty of Pharmacy, University of Benin, Benin City, 300001 Nigeria.

Available online at http://www.tjpr.org

Original Research Article

http://dx.doi.org/10.4314/tjpr.v20i4.2

\title{
Development and characterization of ceftriaxone in-situ gel-forming biodegradable parenteral depot system
}

\author{
Kamil Anum ${ }^{1 *}$, Humaira Naureen', Masood-Ur-Rehman', Tahzeeba Riaz', Atif \\ Sarwar ${ }^{2}$, Aitzaz Ahsan ${ }^{1}$, Erum Butt ${ }^{1}$, Noor-ul-Husnain ${ }^{3}$, Sophia Awais ${ }^{4}$ \\ ${ }^{1}$ Riphah Institute of Pharmaceutical Sciences, Islamabad Pakistan, ${ }^{2}$ Shifa Tameer-e-Millat University H 8/4, Islamabad, \\ ${ }^{3}$ Department of Pharmacy, University of Lahore, Islamabad, ${ }^{4}$ Department of Pharmacy, Hazara University, Mansehra, Pakistan
}

*For correspondence: Email: atif.scps@atmu.edu.pk; Tel: +92-3482044339

Sent for review: 19 May 2020

Revised accepted: 14 March 2021

\begin{abstract}
Purpose: To design parenteral in-situ gel of ceftriaxone using poloxamer as a thermosensitive agent, Carbopol as a $\mathrm{pH}$-sensitive polymer and hydroxypropyl methylcellulose as a viscosity enhancer. Method: Lyophilized ceftriaxone was added in solution form to enhance its solubility and stability. Several formulations were designed using poloxamer $(P$ 188, $F 127$ and $P$ 407) and Carbopol (934P and 940) in varying concentrations, out of which an optimized formulation was chosen on the basis of its gelling capacity and respective transit time. Drug content uniformity, sterility and stability were studied. Drug-polymer and polymer-polymer interaction were determined by differential scanning calorimetry (DSC). Characterization of optimized formulation was carried out by Fourier transform infrared spectroscopy (FTIR). In-vitro release profile was determined by a modified Franz diffusion method. Results: Optimized formulation Q2 was characterized for various physicochemical parameters and found to be stable. In-vitro release study showed first order release pattern. DSC thermograms revealed that the polymers were compatible with each other as no physicochemical interactions were observed. The results were expressed as mean \pm standard deviation ( $S D, p \leq 0.05$ ).

Conclusion: Optimized formulation Q2 provided sustained release up to 10 days following first order release kinetics, and thus can be further developed for large-scale production.
\end{abstract}

Keywords: Ceftriaxone, In situ gel-forming, Biodegradable, DSC, FTIR, Sustained release

\begin{abstract}
This is an Open Access article that uses a fund-ing model which does not charge readers or their institutions for access and distributed under the terms of the Creative Commons Attribution License (http://creativecommons.org/licenses/by/4.0) and the Budapest Open Access Initiative (http://www.budapestopenaccessinitiative.org/read), which permit unrestricted use, distribution, and reproduction in any medium, provided the original work is properly credited.

Tropical Journal of Pharmaceutical Research is indexed by Science Citation Index (SciSearch), Scopus, International Pharmaceutical Abstract, Chemical Abstracts, Embase, Index Copernicus, EBSCO, African Index Medicus, JournalSeek, Journal Citation Reports/Science Edition, Directory of Open Access Journals (DOAJ), African Journal Online, Bioline International, Open-J-Gate and Pharmacy Abstracts
\end{abstract}

\section{INTRODUCTION}

Bacterial meningitis caused by Streptococcus pneumoniae, enters the subarachnoid space causing inflammation not restricting to meninges only but also spreads into brain and spinal cord. Treatment strategy for bacterial meningitis include ceftriaxone monotherapy or in combination with corticosteroids that might continue up to 10-14 days or extending up to 3-4 weeks depending on severity of condition [1]. Frequent administration of antibiotics is painful and could cause patient noncompliance. If a regimen is not followed it leads to plasma fluctuations and antibiotic resistance. Scientists have long been trying to overcome the limitations associated conventional parenteral therapy. Novel parenteral treatment strategies include 
nano particles, solid lipid nano particles, nonbiodegradable parenteral gel and in-situ gel forming biodegradable parenteral depot. Polymers used in nano particles cause cytotoxicity. Solid lipid nano particles cause a burst effect and have limited loading capacity. Implants need surgical insertion and removal at completion of therapy. Injectable parenteral formulation that undergoes phase change by specific stimuli are called parenteral in-situ. Polymers used in in-situ gels are capable of rapid sol-gel transformation triggered by external stimulus such as temperature and $\mathrm{pH}$. In-situ gel forming biodegradable parenteral depot carries sufficient amount of drug, has good tolerability and does not require surgical procedure for its insertion and removal. The present research work was designed to formulate parenteral gel forming biodegradable depot system of ceftriaxone using poloxamer P 407, P188 F 127 and Carbopol 940 and 934P. HPMC K-15M and PVA were added as viscosity enhancers. Few drops of lactic acid/NaHCO 3 were also added to decrease gelation temperature. Five formulations Q1, Q2, Q3, Q4and Q5 were formed using different concentrations of polymers and optimized formulation Q2 was selected on the basis of its gelling capacity and transit time and was subjected to characterization parameters. Invitro release rate was determined by modified Franz diffusion cell and fitted in various pharmacokinetic models. Purity and polymerpolymer/drug-polymer interaction was determined using DSC and FTIR. Stability, sterility and drug content uniformity were also determined. $\mathrm{pH}$ of the optimized formulation Q2 was maintained at 6.0 throughout the procedure to ensure solution form [2-5].

\section{EXPERIMENTAL}

\section{Materials}

Ceftriaxone was a gift by Welwrd Pharmaceuticals, Islamabad, Pakistan. Carbopol 940 and 934P, HPMC K-15M, poloxamer P407, P188, F127, benzyl alcohol, potassium dihydrogen phosphate, lactic acid and sodium bicarbonate were purchased from Sigma Aldrich, USA. All the chemicals used were of analytical grade and used without further purification. Invitro release profile was determined using modified Franz diffusion cell (EMFDC 06) and UV-Visible spectrophotometer (UV-1601).

\section{Lyophilization of ceftriaxone}

Lyophilization of ceftriaxone was done using a Freeze dryer (Biobase 72S100). A Solution of ceftriaxone sodium was prepared in distilled water and stored in freezer for $10 \mathrm{~h}$ which was then subjected to lyophilization, increasing the temperature gradually from -180 to $1700^{\circ} \mathrm{Cfor}$ drying. Pressure range was from 1000 to 5 pascals [6].

\section{Fourier transform infrared spectroscopy (FTIR)}

IR spectra were recorded on FTIR (Cary 630 FTIR). FTIR of ceftriaxone and polymers were obtained at room temperature and pressured over a wavelength of $500-4000 \mathrm{~cm}^{-1}$ for compatibility studies.

\section{Optimization of formulation}

Poloxamer $\mathrm{P} 4407, \mathrm{P} 188$ and $\mathrm{F} 127$ at a concentration of 15 and 20\%, Carbopol 940 and 934P 1\%, PVA 15\% and HPMC K-15M 5, 10,15 $20 \%$ were used to make different formulations as mentioned in Table 1. These formulations were then tested for their compatibility with ceftriaxone, gelling capacity and respective transit time. Formulations that formed precipitates with ceftriaxone or had poor gelling capacity and transit time were not used for further studies. Only formulation Q2 with PVA 15\%, Carbopol 934P 1\%, HPMC K-15M 20\% and poloxamer P407 15\% formed optimized gel with prolonged transit time. Only formulation Q2 (PVA 15\%, Carbopol 934P 1\%, HPMC K15-M $20 \%$ and Poloxamer P 407 15\%) formed optimized gel prolonged transit time. So, formulation Q2 PVA 15\%, Carbopol 934P 1\%, HPMCK-15M 15\% and poloxamer P407 15\% were considered as optimized formulation, and considered for further studies to explore its potential. Composition of different formulation is shown in Table 1.

\section{Preparation of optimized gel Q2}

A weighed amount of poloxamer $P$ (407) was dissolved in phosphate buffer and stored in a refrigerator at $4^{\circ} \mathrm{C}$ for $24 \mathrm{~h}$ until the solution became clear. Carbopol was separately dissolved in phosphate buffer with the help of magnetic stirrer, and stored at room temperature for 24 hours for complete hydration. Same was repeated for Hydroxy propyl methyl cellulose (HPMC) and poly vinyl alcohol (PVA). All the polymers were then mixed with continuous stirring and few drops of benzyl alcohol were added as a preservative. Lyophilized Ceftriaxone was dissolved in distilled water and added with continuous stirring into polymer solution. A few drops of lactic acid and sodium bicarbonate were added in the end to decrease gelling temperature [6]. 
Table 1: Composition of formulations

\begin{tabular}{|c|c|c|c|c|c|c|}
\hline Ingredient & $\begin{array}{c}\text { Content } \\
(\%)\end{array}$ & $\begin{array}{l}\text { Q1 } \\
(\mathrm{ml})\end{array}$ & $\begin{array}{l}\text { Q2 } \\
\text { (ml) }\end{array}$ & $\begin{array}{l}\text { Q3 } \\
\text { (ml) }\end{array}$ & $\begin{array}{c}\text { Q4 } \\
\text { (ml) }\end{array}$ & $\begin{array}{l}\text { Q5 } \\
\text { (ml) }\end{array}$ \\
\hline PVA & 15 & 1.0 & 1.0 & 2.0 & 0.5 & 1.0 \\
\hline Carbopol 934P & 1 & 0.5 & 1.0 & 1.0 & 0.5 & 1.5 \\
\hline Carbopol 940P & 1 & 0.5 & 1.0 & 1.0 & 0.5 & 1.5 \\
\hline \multirow[t]{4}{*}{ HPMC K15M } & 5 & 0.5 & 0.5 & 0.5 & 1.0 & 0.5 \\
\hline & 10 & 0.5 & 0.5 & 0.5 & 1.0 & 0.5 \\
\hline & 15 & 0.5 & 0.5 & 0.5 & 1.0 & 0.5 \\
\hline & 20 & 0.5 & 0.5 & 0.5 & 1.0 & 1.5 \\
\hline \multirow[t]{2}{*}{ P407 } & 15 & 2.0 & 1.5 & 0.5 & 2.0 & 1.0 \\
\hline & 20 & 2.0 & 1.5 & 0.5 & 2.0 & 1.0 \\
\hline \multirow[t]{2}{*}{ F 127} & 15 & 2.0 & 1.5 & 0.5 & 2.0 & 1.0 \\
\hline & 20 & 2.0 & 1.5 & 0.5 & 2.0 & 1.0 \\
\hline \multirow[t]{2}{*}{ P 188} & 15 & 2.0 & 1.5 & 0.5 & 2.0 & 1.0 \\
\hline & 20 & 2.0 & 1.5 & 0.5 & 2.0 & 1.0 \\
\hline $\mathrm{NaHCO}_{3} /$ lactic acid & & 0.1 & 0.1 & 0.1 & 0.1 & 0.1 \\
\hline Ceftriaxone & $2 \mathrm{~g} / 5 \mathrm{ml}$ & $1 \mathrm{ml}$ & $1 \mathrm{ml}$ & $1 \mathrm{ml}$ & $1 \mathrm{ml}$ & $1 \mathrm{ml}$ \\
\hline
\end{tabular}

Formulation code: Q1, Q2, Q3, Q4, Q5

\section{Characterization of optimized in-situ gel}

\section{Appearance and $\mathrm{pH}$}

Clarity of parenteral preparations was measured against dark and light background [7]. $\mathrm{pH}$ was determined using $\mathrm{pH}$ meter probe [8].

\section{Gel strength}

Parenteral solution $(50 \mathrm{ml})$ was taken and placed in a $100 \mathrm{ml}$ graduated cylinder. Solution was gelled thermostatically in a water bath at $37^{\circ} \mathrm{C}$. Gel strength was determined by time in seconds required by $35 \mathrm{~g}$ weight to penetrate up to $5 \mathrm{~cm}$ into gel. All the readings were taken in triplicate and mean \pm SD was recorded [9].

\section{Viscosity}

Viscosity of optimized formulation was determined by Brookfield viscometer using spindle no. 62 at $100 \mathrm{rpm}$ and lowered perpendicularly into the formulation. Viscosity of solution was measured and then solution was heated to $37^{\circ} \mathrm{C}$ and increase in viscosity of gel was determined. The $\mathrm{pH}$ of the formulation was also increased along with temperature because of the $\mathrm{pH}$ dependent polymer, Carbopol [10]. Viscosity changes were also measured at $40{ }^{\circ} \mathrm{C}$ to determine the effect of hyperthermia on viscosity. All the readings were taken in triplets and average was recorded [11].

\section{Sterility}

Formulation was poured on to soybean casein medium and fluid thioglycolate media placed in petri dishes, pre autoclaved at $121{ }^{\circ} \mathrm{C}$ for $15-20$ min at 15 pascal pressure, and incubated at $28 \pm$
$1{ }^{\circ} \mathrm{C}$ for fungal growth and $37 \pm 2{ }^{\circ} \mathrm{C}$ for bacterial growth for a period of 14 days. Incubated media was observed visually for bacterial and fungal growth [12].

\section{Drug content uniformity}

A weighed amount of formulation having amount of drug equivalent to $2 \mathrm{mg}$ was taken and added in a $100 \mathrm{ml}$ volumetric flask. $20 \mathrm{ml}$ of phosphate buffer $\mathrm{pH} 6.0$ was added in it and placed over a magnetic stirrer for $1 \mathrm{~h}$ to get complete dissolution. The volume was made up to $100 \mathrm{ml}$ by phosphate buffer and filtered through a 0.45 $\mu \mathrm{m}$ filter paper. $10 \mathrm{ml}$ of the above solution was taken and diluted up to $100 \mathrm{ml}$ with phosphate buffer, shaken over magnetic stirrer for homogenous mixing and absorbance was determined at $241 \mathrm{~nm}$. Readings were taken in triplets and mean \pm SD was calculated [13].

\section{In-vitro release studies}

In vitro release study was determined using modified Franz diffusion cell (EMFDC 06) and UV-visible spectrophotometer (UV-1601) Donor compartment was filled with gel formulation, and recipient compartment with immersed magnetic stirrer was filled with phosphate buffer $\mathrm{pH} 6$. Donor and recipient compartment were separated by $0.22 \mu \mathrm{m}$ pore size dialysis membrane, soaked 30 mins prior to use. Care was taken to avoid formation of air bubbles at the interface of gel and membrane. Outer jacket was filled with water. Whole assembly was placed on hot plates magnetic stirrer maintained at $37{ }^{\circ} \mathrm{C}$ and $50 \mathrm{rpm}$. Aliquots were removed and refilled by phosphate buffer $\mathrm{pH} 6.0$ and samples that were drawn at time interval $0,24,48,72,96$, $120,144,168,192,216$ and $240 \mathrm{~h}$ were 
subjected to UV analysis at $241 \mathrm{~nm}$. Data obtained was fitted into different pharmacokinetic models to determine release profile of formulation Q2 [14].

\section{Differential scanning calorimetry (DSC)}

Calorimetric studies of prepared in-situ gel were performed by taking 4-5 mg sample and placing it in hermetically sealed aluminium pans and scanning at $50^{\circ} \mathrm{C} / \mathrm{min}$ under nitrogen gas flow at $20 \mathrm{ml} / \mathrm{min}[15]$

\section{Stability studies}

Stability study were performed by placing sample in stability chamber at $40 \pm 2^{\circ} \mathrm{C}$ and $75 \pm 5 \mathrm{RH}$, and at $25 \pm 2^{\circ} \mathrm{C}$ and $60 \pm 5 \mathrm{RH}$ for 6 months as per $\mathrm{ICH}$ guidelines, and their appearance, $\mathrm{pH}$ and clarity were assessed [16].

\section{Statistical analysis}

All mean values were presented with their standard deviation mean $\pm S D(n=5)$. Statistically significant differences were determined using one-way ANOVA with $p<0.05$ considered statistically significant.

\section{RESULTS}

\section{Infra-red spectra}

Polymers were pure and their spectra was almost similar to literature. For ceftriaxone absorption peaks at $3422.6 \mathrm{~cm}^{-1}$ exhibited stretching vibration of $\mathrm{N}-\mathrm{H}$ and $\mathrm{O}-\mathrm{H}$ groups. $1735.1 \mathrm{~cm}^{-1}$ peak showed presence of carbonyl group, while the peaks at 1366.1 and smaller peaks at 1287.8 and $1103.3 \mathrm{~cm}^{-1}$ showed stretching movement of $\mathrm{C}-\mathrm{N}, \mathrm{C}-\mathrm{O}$ and $=\mathrm{C}-\mathrm{H}$ respectively. FTIR peaks of in-situ gel of ceftriaxone were comparable to active pharmaceutical ingredient (Figure 1 A). Sharp peaks at $1718.3 \mathrm{~cm}^{-1}$ in Carbopol showed vibrational stretching of $\mathrm{C}=\mathrm{O}$ group, whereas $3451.0 \mathrm{~cm}^{-1}$ band was attributed to $\mathrm{C}-\mathrm{H}$ stretching vibration. Bands in range of 1053.6 $\mathrm{cm}^{-1}$ show C-O-C stretching, while stretching of $\mathrm{O}-\mathrm{H}$ was demonstrated by bands present at $1371.7 \mathrm{~cm}^{-1}$ (Figure $1 \mathrm{C}$ ) [13].

For HPMC broad spectrum bands seen at 3600$3100 \mathrm{~cm}^{-1}$ with maximum peak at $3451.5 \mathrm{~cm}^{-1}$, were attributed to $\mathrm{O}-\mathrm{H}$ group vibration. Peak at $2898.0 \mathrm{~cm}^{-1}$ showed asymmetric and symmetric stretching of $\mathrm{CH}_{2}$ groups. Smaller peaks at $1499.0 \mathrm{~cm}^{-1}$ show propyl stretching vibration. Asymmetric $\mathrm{C}-\mathrm{O}-\mathrm{C}$ for allylic ethers showed stretching bands at $1053.1 \mathrm{~cm}^{-1}$ while, $\mathrm{C}-\mathrm{OH}$ band was observed at $941.2 \mathrm{~cm}^{-1}$ (Figure $\left.1 \mathrm{D}\right)$ [14].

FTIR spectra of poloxamer P407 showed $\mathrm{C}-\mathrm{H}$ stretching peak at $2875.6 \mathrm{~cm}^{-1}$ while $1086.5 \mathrm{~cm}^{-1}$ peak was for $\mathrm{O}-\mathrm{H}$ bending and $1343.7 \mathrm{~cm}^{-1}$ was attributed to C-O stretching (Figure $1 \mathrm{E}$ ) [15].

FTIR spectra of PVA showed stretching band of $2937.1 \mathrm{~cm}^{-1}$ for alkyl stretching, $3250 \mathrm{~cm}^{-1}$ and broad peaks for hydrogen bonding. Peaks observed at $1645.6 \mathrm{~cm}^{-1}$ showed stretching of $\mathrm{C}=\mathrm{O}$ from acetate groups. Figure $1 \mathrm{~F}$. The formulation showed no extra peaks supporting the fact that polymers and ceftriaxone were compatible with each other (Figure 1).

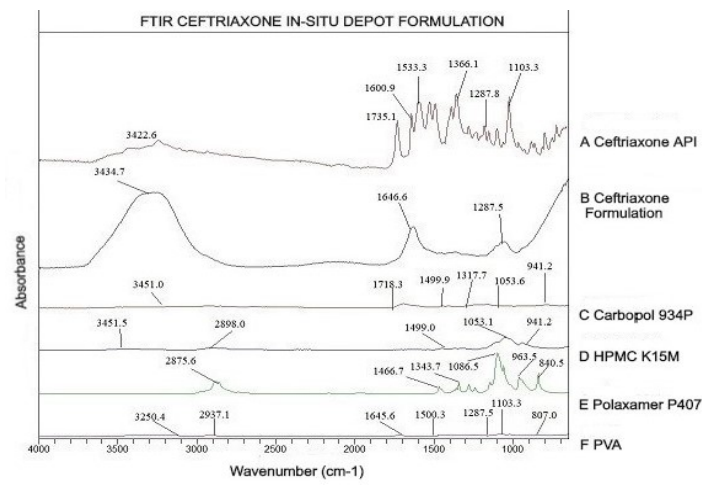

Figure 1: FTIR spectra ceftriaxone and polymers

\section{Appearance and pH}

The formulation was light yellow in colour, which was attributed to colour of ceftriaxone. $\mathrm{pH}$ of formulation was maintained at 6.0 by using phosphate buffer, determined by $\mathrm{pH}$ meter and found to be in the range of 5.8 to 6.2 at room temperature.

\section{Gel strength}

Gel strength increased with increase in temperature for thermally sensitive polymer i. e poloxamer and with increase in $\mathrm{pH}$ for $\mathrm{pH}$ dependent polymer i.e. Carbopol [1718].

Table 2: Gel strength of formulation

\begin{tabular}{lcc}
\hline $\begin{array}{l}\text { Temperature } \\
\left({ }^{\circ} \mathbf{C}\right)\end{array}$ & $\mathbf{p H}$ & $\begin{array}{c}\text { Gel strength }(\mathbf{s}) \\
\text { (mean } \pm \text { SD) }\end{array}$ \\
\hline $\mathbf{2 5}$ & 6.0 & $70 \pm 0.02$ \\
$\mathbf{2 8}$ & 6.3 & $91 \pm 0.05$ \\
$\mathbf{3 1}$ & 6.7 & $107 \pm 0.05$ \\
$\mathbf{3 4}$ & 6.9 & $112 \pm 0.04$ \\
$\mathbf{3 7}$ & 7.2 & $117 \pm 0.03$ \\
$\mathbf{4 0}$ & 7.2 & $119 \pm 0.04$ \\
\hline \multicolumn{2}{l}{ (Values are expressed as mean $\pm S . D(n=5), p<0.05)$}
\end{tabular}

Trop J Pharm Res, April 2021; 20(4): 676 


\section{Viscosity}

Viscosity of formulation increased by increase in temperature and $\mathrm{pH}$, increasing gradually from 25 to $30^{\circ} \mathrm{C}$ and then increased dramatically at $37^{\circ} \mathrm{C}$. Viscosity was also measured at $40^{\circ} \mathrm{C}$ to determine effects of physiological conditions on viscosity. There was no significant change in viscosity at $40^{\circ} \mathrm{C}$.

Table 3: Viscosity of formulation (mean \pm SD)

\begin{tabular}{lc}
\hline Temperature $\left({ }^{\circ} \mathbf{C}\right)$ & Viscosity (cPs) \\
\hline 25 & $266.67 \pm 0.04$ \\
29 & $701.66 \pm 0.01$ \\
34 & $1109.33 \pm 0.02$ \\
37 & $2279.25 \pm 0.05$ \\
40 & $2346.19 \pm 0.02$ \\
\hline
\end{tabular}

Values are expressed as mean $\pm S . D(n=5) ; p<0.05)$

\section{Sterility}

The formulation was sterile even after incubation up to 14 days in fluid thioglycolate medium (FT) at $37^{\circ} \mathrm{C}$ and soybean casein medium at $28^{\circ} \mathrm{C}$. There was no evidence of microbial or fungal growth as no turbidity appeared.

\section{Drug content uniformity}

The percentage of drug content of formulation was in the range of 95.5 to $98.9 \%$ which was within the official limits, $100 \pm 5 \%$. Drug was uniformly distributed in formulation.

\section{In-vitro drug release}

Table 5 explains the release pattern of formulation Q2 determined by using modified Franz diffusion cell. Data suggests that formulation Q2 released the drug constantly over the period of time and no burst effect occurred.

\section{Thermal properties}

Five milligrams of sample was weighed and heated in aluminium plates at a scan rate of $50^{\circ} \mathrm{C} / \mathrm{min}$ under nitrogen gas flow at $20 \mathrm{ml} / \mathrm{min}$. Two endothermic peaks at 75 and $145^{\circ} \mathrm{C}$ showed the dehydration process of ceftriaxone and large exothermic peak at $270^{\circ} \mathrm{C}$ showed melting/ decomposition of ceftriaxone, which were close to literature $240-265^{\circ} \mathrm{C}$. Data illustrates ceftriaxone melted before decomposition $[19,20]$.

Table 5: Cumulative release profile of the optimized formulation (mean \pm SD)

\begin{tabular}{lc}
\hline Time (h) & Drug release (\%) \\
\hline 0 & $0 \pm 0.022$ \\
24 & $5.5 \pm 0.04$ \\
48 & $20.2 \pm 0.010$ \\
72 & $43.5 \pm 0.042$ \\
96 & $47.6 \pm 0.01$ \\
120 & $52.9 \pm 0.020$ \\
144 & $61.1 \pm 0.01$ \\
168 & $71.1 \pm 0.045$ \\
192 & $81.2 \pm 0.051$ \\
216 & $90.5 \pm 0.045$ \\
240 & $97.6 \pm 0.023$ \\
\hline Values are expressed as mean $\pm S . D(n=5)] ; p<0.05$
\end{tabular}

The release data obtained were fitted in pharmacokinetic models and the outcome indicate sustained first order release kinetics for 10 days.

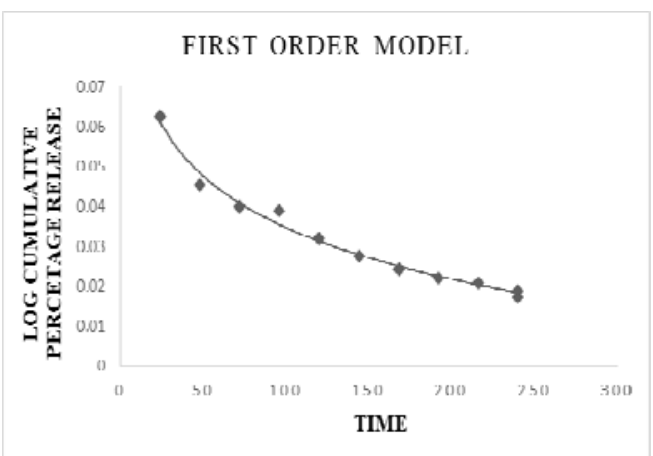

Figure 2: First order release profile of formulation Q2

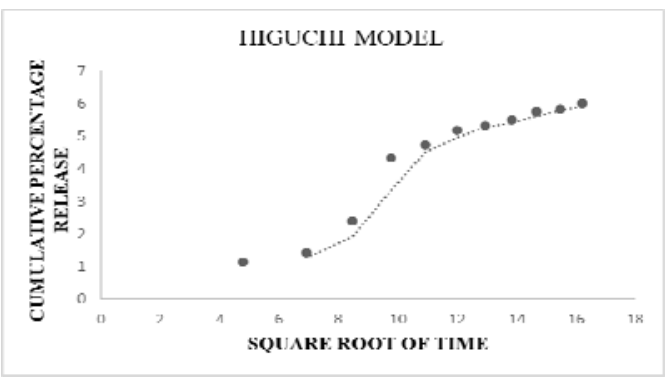

Figure 3: Higuchi release profile of formulation Q2

Table 4: Physical properties of formulation

\begin{tabular}{llcccc}
\hline Formulation & Colour & Homogeneity & Grittiness & pH & $\begin{array}{c}\text { Drug content } \\
(\%, \text { mean } \pm \text { SD) }\end{array}$ \\
\hline Q2 & Opaque yellow & +++ & - & 6.0 & $96.3 \pm 0.03 \%$ \\
Q2 & Opaque yellow & ++++ & - & 6.0 & $98.9 \pm 0.03 \%$ \\
Q2 & Opaque yellow & +++ & - & 6.0 & $95.5 \pm 0.02 \%$ \\
\hline
\end{tabular}




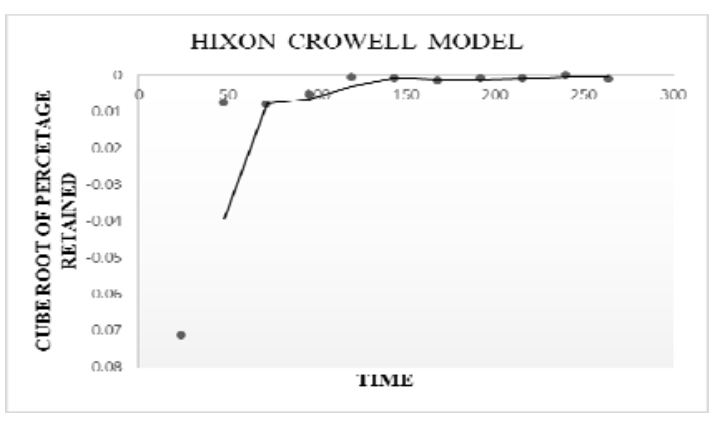

Figure 4: Hixon Crowell release profile of formulation Q2

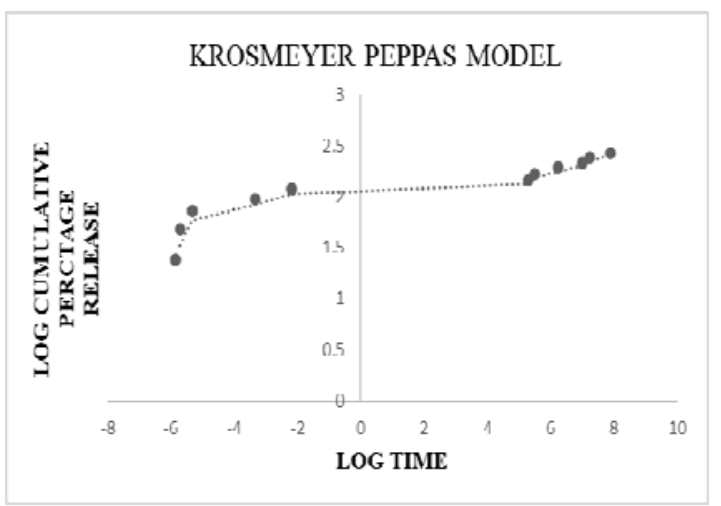

Figure 5: Krosmeyer Peppas release profile of formulation Q2

Peaks were seen at $75^{\circ} \mathrm{C}$ for $\mathrm{P} 407$ and Carbopol and were close to literature peaks of $61^{\circ} \mathrm{C}$ for P407 and $76^{\circ} \mathrm{C}$ for Carbopol [21]. No incompatibility was seen among the polymers and with the drug (ceftriaxone) as there was no change in peak values as that of literature. (Figure 6).

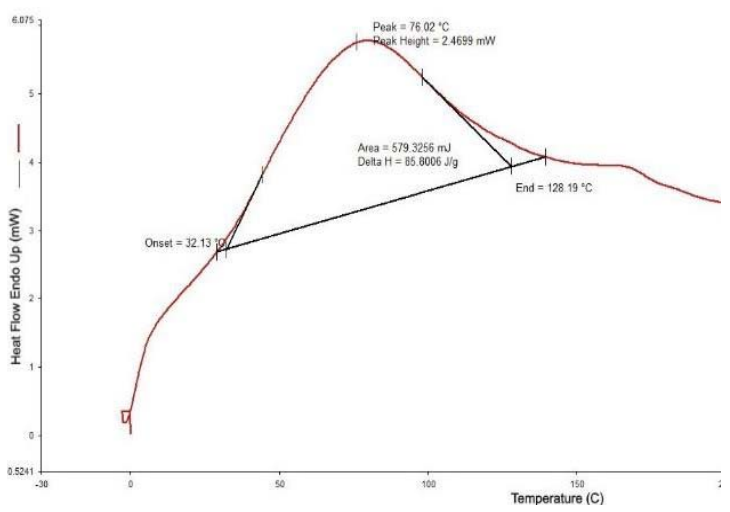

Figure 6: DSC thermogram of formulation Q2

\section{Stability}

All the samples were stable and remained clear throughout the storage period.

\section{DISCUSSION}

In-situ parenteral preparations undergo a phase change when they meet a specific stimulus like temperature, $\mathrm{pH}$ or some physical stimuli. Parenteral in-situ gel formation provides a prolonged release mechanism, and require significantly smaller doses to obtain desired therapeutic effect. Injectable in-situ polymers have compatibility with a wide range of pharmaceutical products. The present work was designed to make ceftriaxone in-situ gel forming biodegradable parenteral system using Carbopol 934P and poloxamer P407.

The viscosity and gel strength defines the release pattern of formulation. A phosphate solution of polymers showed low viscosity at room temperature and a sharp rise in viscosity by increase in temperature. Viscosity was also determined at $40^{\circ} \mathrm{C}$ to determine the effects of hyperthermia on the formulation. Increasing the temperature did not cause any significant increase in viscosity. Gel strength was directly proportional to viscosity [11]

Thioglycolate and soybean casein medium were used for sterility determination as per the British Pharmacopoeia defined method. After an incubation period of 14 days, petri dishes were clear showing the formulation was sterile.

Franz diffusion cell helps to determine the amount of drug diffused from formulation and amount of drug washed away. In present study, modified Franz diffusion cell with a dialysis membrane of $0.22 \mu \mathrm{m}$ pore size was used for determination of in-vitro release pattern. In-situ depot of ceftriaxone provided a constant release, following first order over a period of 10 days. The data supports the fact that in-situ gel is a promising mechanism for providing effective therapeutic effects over an extended period of time [14].

Thermal analysis is used to determine interaction between active pharmaceutical ingredient and polymers. Any changes in endothermic or exothermic peaks or appearance of new peaks determine the interaction between polymers, or of the polymers with active pharmaceutical ingredient. No change in peaks shows that components are compatible with each other. A Phase transition or conformational changes in a system can be determined by DSC. The Sample was heated on aluminium plates at $50^{\circ} \mathrm{C} / \mathrm{min}$ under nitrogen gas flow rate of $20 \mathrm{ml} / \mathrm{min}$. Results showed that polymers were well compatible with the API as there were no new peaks [15]. 
Freeze drying/lyophilization is the process of removing water from components by first freezing them and then subjecting them to sublimation under a high vacuum. Water vapours are caught on the surface of the condenser, and this provides a porous product that can easily be reconstituted by adding a suitable diluent. Keeping in view the benefits of lyophilization active pharmaceutical ingredient was lyophilized and stored in a glass syringe.

\section{CONCLUSION}

The optimized formulation Q2 provided in-vitro release over a period of 10 days, following $1^{\text {st }}$ order release pattern. A sustained release profile of up to 10 days will improve patient compliance and minimize plasma fluctuations of the drug. Biodegradable polymers used in the formulation of the in-situ gel will not require surgical insertion and removal.

\section{DECLARATIONS}

\section{Acknowledgement}

Ourgratitude goes to $\mathrm{Dr}$ Gul Shehnaz, Dr Atif Sarwar, Dr Rashid Ali Khan and Dr Humaira Naureen for their kind guidance at every step of the research.

\section{Conflict of interest}

No conflict of interest is associated with this work.

\section{Contribution of authors}

We declare that this work was done by the authors named in this article and all liabilities pertaining to claims relating to the content of this article will be borne by the authors. Kamil Anum, Atif Sarwar and Tahzeeba Riaz designed the study. Masood-Ur-Rehman and Kamil Anum conducted literature search, experimental work, data analysis and drafted the manuscript. Erum Butt, Noor ul Husnain and Sophia Awais helped in carrying out the experimental work. All the authors reviewed and approved the final manuscript for publication.

\section{Open Access}

This is an Open Access article that uses a funding model which does not charge readers or their institutions for access and distributed under the terms of the Creative Commons Attribution License (http://creativecommons.org/licenses/by/
4.0) and the Budapest Open Access Initiative (http://www.budapestopenaccessinitiative.org/rea d), which permit unrestricted use, distribution, and reproduction in any medium, provided the original work is properly credited.

\section{REFERENCES}

1. Hoffman O, Weber JR. Pathophysiology and treatment of bacterial meningitis. Ther Adv Neurol Disord. 2009; 2(6): 401-412.

2. Veyries ML, Couarraze G, Geiger S, Agnely, F, Massias $L$, Kunzli B, Faurisson $F$, Rouveix B. Controlled release of vancomycin from poloxamer 407 gels. Int $J$ Pharm1999; 192: 183-193.

3. Fakhari A, Corcoran $M$, Schwarz A. Thermogelling properties of purified poloxamer 407. Heliyon 2017; 3: 126.

4. Sahoo S, Chakrabortil CK, Mishra SC, Nanda UN. Analysis of environmentally responsive biodegradable smart carbopol polymer. Int. J Pharm Sci Rev Res 2011; 9(1): 8-13.

5. Kaul A, Hazari PP, Rawat $H$, Singh B, Kalawat TC, Sharma S, Babbar AK, Mishra AK. Preliminary evaluation of technetium-99m-labeled ceftriaxone: infection imaging agent for the clinical diagnosis of orthopaedic infection. Int J Infect Dis 2013; 17: 263-270.

6. Katakam M, Ravis WR, Banga AK. Controlled release of human growth hormone in rats following parenteral administration of poloxamer gels. J Control Release 1997; 49: 21-26.

7. Gupta H, Jain S, Mathur R, Mishra $P$, Mishra AK. Sustained ocular drug delivery from a temperature and pH triggered novel in-situ gel system. Drug Deliv 2007; 14: $507-515$.

8. Swati J, Nirupama S, Bhanudas SK. Optimization of thermo reversible in-situ nasal gel of Timolol Maleate. Scientifica 2016; 1-12.

9. Farid RM, Etman MA, Nada AH, Ebian AEAR. Formulation and In Vitro Evaluation of Salbutamol Sulphate In Situ Gelling Nasal Inserts. AAPS PharmSciTech. 2013; 14(2): 712-8.

10. Chaudhary B, Verma S. Preparation and evaluation of novel in-situ gels containing acyclovir for the treatment of oral herpes simplex virus infections. Scient World $J$ 2014; 1 -8.

11. Mahajan HS, Gattani S. In situ gels of Metoclopramide Hydrochloride for intranasal delivery: In vitro evaluation and in vivo pharmacokinetic study in rabbits. Drug Deliv. 2010 Jan; 17(1): 19-27.

12. Agrawal AK, Das M, Jain S. In situ gel systems as 'smart' carriers for sustained ocular drug delivery. Expert Opin Drug Deliv. 2012; 9(4): 383-402.

13. Zakaria AS, Afifi SA., Elkhodairy KA. Newly developed topical cefotaxime sodium hydrogels: Antibacterial activity and in vivo evaluation. BioMed Res Int. 2016; 3: $1-15$. 
14. Attama AA, Okafor CE, Builders PF, Okorie $O$. Formulation and in vitro evaluation of a pegylated microscopic lipospheres delivery system for ceftriaxone sodium. Drug Deliv. 2009; 16(8): 448-457.

15. Garala K, Joshi $P$, Patel J, Ramkishan A, Shah $M$. Formulation and evaluation of periodontal in situ gel. Int J Pharm Investig. 2013; 3(1): 29.

16. Agrawal S, Pancholi SS, Jain NK. Agrawal GP. Hydrotropic solubilization of nimesulide for parenteral administration. Int J Pharm. 2004; 274: 149-155.

17. Burugapalli K, Bhatia D, Koul V, Choudhary V. Interpenetrating polymer networks based on poly (acrylic acid) and gelatin. I: Swelling and thermal behavior. J Appl Polym Sci. 2001 Oct 3; 82(1): 217-27.
18. Can A, Erdal M, Güngör S, Özsoy Y. Optimization and Characterization of Chitosan Films for Transdermal Delivery of Ondansetron. Molecules. 2013; 18(5): 54553471.

19. Singh K, Harikumar SL. Injectable in-situ gelling controlled release drug delivery system. Int. J. Drug Dev. Res. 2012; 4(2): 56-69.

20. Gupta S. Carbopol/Chitosan Based pH Triggered In Situ Gelling System for Ocular Delivery of Timolol Maleate. Sci Pharm. 2010; 78(4): 959-976.

21. Kempe S, Mäder K. In-situ forming implants - an attractive formulation principle for parenteral depot formulations. J Control Rel 2012; 161: 668-679. 